\title{
Kadim bir şifreleme yönteminin kültürümüzdeki yansıması: Hatt-ı şecerî
}

\section{Bünyamin TAŞ1} APA: Taş, B. (2019). Kadim bir şifreleme yönteminin kültürümüzdeki yansıması: Hatt-1 şecerî.
RumeliDE Dil ve Edebiyat Araştırmalar Dergisi, (16), 328-339. DOI: 10.2900o/rumelide.618948

\section{$\ddot{O} \mathbf{z}$}

El yazması eserlerde, birbirinden farklı yöntemlerle tasarlanmış standart dışı alfabe örnekleriyle karşılaşılabilmektedir. Herkesçe bilinmemeleri itibarıyla birer gizli yazı türü olarak da kabul edilen bu alfabelerden biri de hatt-ı şecerîdir. Adını şeklinin ağaca benzemesinden alan söz konusu yazıya muhtelif türdeki Türkçe, Arapça ve Farsça el yazmalarında tesadüf edilebilmektedir. Arap yazısının ebced diziliminden faydalanarak tasarlanan bu alfabenin, geçmişte bazı bilgileri gizli bir şekilde kaydetmek veya güvenli olarak nakletmek amacıyla kullanıldığı anlaşılmaktadır. Yine şeklinden ötürü hatt-ı nahlî, hatt-ı servî, hatt-ı şecer, kalem-i miscer, kalem-i müşeccer, kalem-i serv ve kalem$i$ şecerî gibi birçok farklı adla da anılan söz konusu alfabe, kadim bir şifreleme yönteminden yararlanılarak tesis edilmiştir. Bu yöntem, el yazması kayıtlarından ve sair kaynaklardaki bilgilerden anlaşıldığı kadarıyla en az 2.500 yıllık bir geçmişe ve kullanıldığı dönem itibarıyla da evrensel bir yaygınlı̆̆a sahiptir. Bahse konu yöntemin İslam muhitindeki bir yansıması olan hatt-ı şecerî, el yazmalarındaki uygulama örneklerine ve kaynaklardaki başka kayıtlara göre temelde üç farklı modele sahiptir. Bu çalışmada hatt-ı şecerînin tafsilatlı bir tanımı yapılarak menşei konusu tartışılmış, mevcut örnekler üzerinden belli başlı modelleri belirlenip müstakil türler olarak tasnifleri yapılmış ve el yazmalarındaki işlevlerine bakarak daha çok ne tür metinlerde hangi amaçlarla kullanıldıkları belirlenmeye çalışılmıştır.

Anahtar kelimeler: Hatt-ı şecerî, şifre alfabeleri, gizli ilimler.

\section{The reflection of an ancient encryption method in Islamic culture: Ḥațț-i shajarī}

\begin{abstract}
Some manuscripts contain examples of non-standard alphabets designed by different methods. Only a limited segment can read these alphabets. Therefore, they are considered as a type of secret writing. One of these alphabets is hatt-i shajarī. It is named as hatt-i shajari because its shape resembles a tree and because of its shape, it is also called in many different names as hatt $-i$ nahlī, hatt $-i$ servī, hatti shajar, kalem-i miscer, kalem-i mushajjar, kalem-i serv and kalem-i shajari. This writing style can be found in various Turkish, Arabic and Persian manuscripts. Hatt-i shajari is basically designed using abjad, the Semitic alphabet system. This alphabet has been used in the past to secretly record or securely transmit some information. The alphabet was established using an ancient encryption method. This method has a history of at least 2,500 years as understood from the manuscript records and other sources. It has a universal prevalence as of its period of use. Hatt-i shajari, which is a reflection of this ancient method in Islamic culture, has basically three different models according to the application examples in manuscripts and other records in the sources. In this study, the definition of hatt-i shajari has been made in a way, the origin problem has been discussed and the main models
\end{abstract}

1 Dr. Öğr. Üyesi, Aksaray Üniversitesi, Fen Edebiyat Fakültesi, Türk Dili ve Edebiyatı Bölümü (Aksaray, Türkiye), bunyamintas@yandex.com, ORCID ID: 0000-0002-0501-6496 [Makale kayıt tarihi: 12.07.2019-kabul tarihi:20.09.2019; DOI: $10.29000 /$ rumelide.618948] 


\begin{abstract}
have been defined through the existing examples. In addition, these models are classified as individual species. Then, by looking at the functions of the existing records in the manuscripts, it was tried to determine for what purposes this text is mostly used in which texts.
\end{abstract}

Key words: Ḥaț-i shajarī, encryption alphabets, occultism.

\title{
Giriş
}

İnsanoğlu tarih boyunca bazen güvenlik ve gizlilik kaygısından hareketle, bazen pratik iletişim aracı işleviyle bazen de bir çeşit eğlenme vasıtası olarak umumî iletişimin en yaygın aracı olan ve mümkün derece anlaşılır olması beklenen genel yazı sitemlerinin yanı sıra, ancak ehlince anlaşılabilecek kimi özel/şifreli yazllar da ihdas etmiştir. Geçmişten günümüze özellikle devlet sırlarının düşmanlar tarafından ele geçirilmemesi için posta teşkilatlarında ve casusluk faaliyetlerinde bu tür şifreli iletişim araçlarına başvurulmuştur (Harekât, 1992; Muhammedî-Feşârekî ve Şîrânî, 1390). Türkçe, Arapça ve Farsça el yazması eserlerdeki kayıtlardan görüldüğü kadarıyla geçmişte İslam dünyasının hemen her yerinde mezkûr amaçlarla kullanıldığı anlaşılan hatt-ı şecerî de bu tür bir şifreli yazı tekniğidir. Türkçe el yazmalarında birçok örneğine tesadüf edilen bu yazı türü hakkında Türkiye'deki akademik yayınlarda özet mahiyetinde bilgiler verilip yazının menşei ve farklı modelleri üzerinde durulmamıştır. Aynı şekilde Farsça yayınlarda da yazının İran'daki el yazmalarında tesadüf edilen yaygın kullanım şekline temas edilip yukarıda belirtilen hususlar mevzubahis edilmemiştir.

Tespit edilebildiği kadarıyla Türkçe bir akademik yayında hatt-ı şecerîden ilk söz eden Âmil Çelebioğlu olmuştur. Çelebioğlu, Decourdemanche'ye (1899: 262) atfen "ordu teçhizatı, yiyecek, içecek" vb. alanların yanı sıra edebiyatta daha ziyade lugazların cevabına medlulen kullanıldığını belirttiği bu hattın kültür ve edebiyatımızda en yaygın kullanılan şifre alfabe olduğu tahminini izhar etmiştir. Yayında hattın adı kalem-i şecerî şeklinde kaydedilip kalem-i servek terkibiyle adlandırıldığı da belirtilmiş, ama hatt-ı şecerî kavramı anılmamıştır. Çelebioğlu, bu yazının ebced tertibine göre tesis edildiğini belirttikten sonra Şeyhülislam Âşirefendizâde Mehmed Hafid Efendi'nin Ed-Dürerül-Müntehabâti'lMensûre fí-Islâhi'l-Galatâti'l-Meşhûre'sinde kaydedilen (1221: 359) iki farklı tertip yönteminden bahsederek Türkçe el yazmalarında kullanılan en yaygın yöntemi içeren bir lugazı örnek olmak üzere iktibas etmiştir (1998: 509-510). Özer Şenödeyici, klasik metinlerdeki görsel şiirleri konu ettiği makalelerinde $(2008 ; 2009)$ bu hattı örnekleyen iki el yazması kaydına yer verip yazıyı Çelebioğlu'nun tarifi üzere kısaca tanıtmış, çeşitleri üzerinde durmamıştır. Şenödeyici, tespit ettiği kayıtlardan hareketle yazının müşeccer kavramıyla da ifade edildiğini belirlemiştir. İlgili makalelerin geliştirilerek kitaba dönüştürüldüğü çalışmada ise Millî Kütüphanede 06 Mil yz A 2714 arşiv numarasıyla kayıtlı bir mecmuada tespit ettiği "Hatt-ı Şecer Bu Hisâb Üzredir" serlevhasiyla takdim edilen tabloyu yayımlamıştır (2012: 42). Böylece söz konusu yazının hatt-ı şecer adıyla anıldığını da tespit etmiştir. Esra Egüz ise Priştineli Begzâde Nûrîye ait bir dîvân nüshasında bulunan şifreli yazıları konu ettiği yazısında, ilgili el yazmasında medlulü hatt-ı şecerî ile kaydeden lugaz örneklerini yayımlamıştır (2010).

İran Millî Kütüphanesinde bulunan bazı el yazmalarında karşılaştığı örneklerden hareketle konu hakkında müstakil bir makale neşreden Seyyid Ali Kesâî (1387), ilgili yazı türünün isimlendirilmesi noktasında, gördüğü örneklerden ve sair kaynaklardan faydalanarak hatt-ı şecerî, hatt-ı şecer, hatt-ı servî, hatt-ı nahlî, kalem-i şecerî, kalem-i müşeccer, kalem-i serv ve kalem-i miscer rivayetlerini nakletmiştir. Makalede mevzu hakkındaki Farsça literatür hülasa edilmiştir. Yazıdaki verilere göre Farsça literatürde de Kesâî̀ye gelinceye kadar konu müstakil olarak ele alınmamıştır. Kesâî ise hatt-ı şecerînin kökeni ve farklı tasarımları konusunu tartışmadan İran'da yaygın olduğu anlaşılan modeli 
tanıtıp bu model üzerinden mevzunun İran toplumuna sirayet eden muhtelif yönlerine dikkat çekmiştir. Ayrıca hatt-ı şecerî hakkında genel bilgi sunan el yazması eserlerden iki farklı tablo görüntüsü ile yine el yazmalarında bu hatla yazıldığını tespit ettiği iki kısa kaydın fotoğrafını yayımlamıştır.² Kesâînin makalesinden sonra yazılan ve şifreli yazılar hakkında genel bir tasvir sunan iki makalede ise sair şifreli alfabelerle birlikte hatt-ı şecerînin İran'da yaygın olan modelinin temel özelliklerini vermekle iktifa edilmiş, herhangi bir el yazması kaydı nakledilmemiştir (Zâkirî, 1388; Muhammedî-Feşârekî ve Şîrânî, 1390).

Bu çalışmada hatt-ı şecerînin genel bir tanımı yapıldıktan sonra bahsi geçen şifreleme modelinin menşei tartışılarak farklı kaynaklarda tespit edilen değişik hatt-ı şecerî modelleri tanıtılacaktır.

\section{Hatt-ı şecerî}

\section{Tanım}

Şekil itibarıyla basit bir ağaç formunu andıran hatt-ı şecerî, Arap alfabesinin ebced tertibi esasına dayalı bir şifreli yazı tasarımıdır. Bu itibarla hatt-ı şecerînin anlaşılması için öncelikle ebced tertibinin bilinmesi gerekmektedir. Ebced tertibi, Arap alfabesinin en eski dizilim modeli olup, Emevî halifesi Abdülmelik b. Mervân döneminde (685-705) ihdas edilen şekil benzerliğine dayalı mevcut tertipten farklıdır (Uzun, 1994). Ebced dizilimine göre Arap alfabesinin düzeni aşağıdaki gibidir:

\begin{tabular}{|c|c|c|c|c|c|c|c|c|c|c|c|c|c|}
\hline ن & r & J & ك5 & ى & b & $\tau$ & j & $g$ & 0 & د & ج & ب & 1 \\
\hline 50 & 40 & 30 & 20 & 10 & 9 & 8 & 7 & 6 & 5 & 4 & 3 & 2 & 1 \\
\hline$\dot{\varepsilon}$ & ظ & ض & $\dot{j}$ & $\dot{\tau}$ & $ث$ & $ت$ & ش ش & J & ق & ص & ف & $\varepsilon$ & س \\
\hline 1000 & 900 & 800 & 700 & 600 & 500 & 400 & 300 & 200 & 100 & 90 & 80 & 70 & 60 \\
\hline
\end{tabular}

Yukarıdaki tabloda harflerin altında yazan değerler, ilgili harfin ebced tertibindeki sayısal karşılı̆̆ını göstermektedir. Tarih boyunca muhtelif alfabe sistemlerinde görüldüğü gibi (Faulmann, 2001: 79-80, 166-167) Arap alfabesinin en eski düzeni olan ebced diziliminde de harfler aynı zamanda rakam yerine kullanılmıştır. Böylece rakamlar için özel göstergelerin kullanıldığı sonraki dönemlerde de alfabedeki göstergelerin sayısal özelliği unutulmadan değişik şekillerde işlev görmeye devam etmiştir. Arap alfabesinin eski dizilimi olan ebced tertibinin unutulmadan yaşaması da söz konusu işlevlerle alakalı olmalıdır. Nitekim ebced tertibi günümüzde bir tür alfabe dizilimi olmaktan ziyade yukarıdaki sayısal göstergelerin dizgesi olarak hatırlanmaktadır.

Ebced diziliminin daha kolay ezberlenmesini veya hatırda kalmasını sağlamak için harfler alfabedeki sıralarına uygun bir şekilde hiçbir anlamı olmayan sekiz kelime ile formüle edilmiştir (Karabey, 2015: 11). Kelimelerden ilki ebced şeklinde okunduğu için alfabeye de bu ad verilmiştir. Söz konusu kelimeler şu şekildedir:

\footnotetext{
2 Kesâ̂’’nin İran Millî Kütüphanesinde tespit ettiği nüshaların kaydı kendi nakline göre şu şekildedir: 1) Arşiv No: 18589 (v. 90 ${ }^{\text {b) }}$ 2) Hâş̧iye-i Mollâ 'Abdullâh ve Şerh-i Şevâhid-i Suyûtî, Arşiv No: 18588 (v. $75^{\text {b) }}$. 3) Arşiv No: 15802 (s. 21). 4) Mefâtîhu'r-Rumûz, Arşiv No: 12359 (v. $7^{\mathrm{a}}$ ).
} 


\begin{tabular}{|c|c|c|c|c|c|c|c|}
\hline 8 & 7 & 6 & 5 & 4 & 3 & 2 & 1 \\
\hline ضظغ & ثخذ & قرشت & سعفص & كلمن & حطى & هوز & ابجد \\
\hline Dazig & Sehhaz & Karaşet & Sa'fas & Kelemen & Huttî & Hevvez & Ebced \\
\hline
\end{tabular}

Hatt-ı şecerînin en yaygın modeli bu sekiz kelimeyi esas alarak tesis edilmiştir. Yukarıdaki kelimelerden her birine sırasıyla numara verilmiş ve dolayısıyla sekiz birim elde edilmiştir. Şifreli yazı, harflerin bu sekiz birimden hangisinin içinde konumlandığını ve bulunduğu birimde kaçıncı sırada yer aldığını göstermeye dayalıdır. Dik çekilen düz bir çizginin sağına ve soluna genellikle yukarı meyilli eğik çizgiler koymak suretiyle resmedilen yazının sağ tarafındaki çizgiler alfabeyi formüle eden sekiz kelimeye, sol tarafındaki çizgiler ise harfin ilgili kelime içinde kaçıncı sırada yer aldığına delalet eder. ${ }^{3}$ Örneğin kitâb (كتاب) kelimesinin hatt-ı şecerî ile imlası şu şekilde yapılır: Kelimenin ilk harfi olan kef (ك)), ebced dizilimini formüle eden söz konusu sekiz kelimeden dördüncüsünün içinde (كلمن) ilk sırada yer almaktadır. Dolayısıyla dik çizginin să̆ına çekilen dört eğik çizgi ile bu harfin, ebced kelimelerinin dördüncüsünde yer aldığı, dik çizginin soluna çekilen bir eğik çizgi ile de ilgili ebced kelimesinin ilk harfi olduğu belirtilir. Aynı yolla te $(ت)$ harfi için dik çizginin sağına altı, soluna dört; elif $(\)$ harfi için sağa ve sola birer çizgi; be (ب) içinse sağa bir, sola iki çizgi çekilir ve ortaya çlkan göstergeler Arap alfabesindeki gibi soldan sağa dizilerek yazı kurulur:

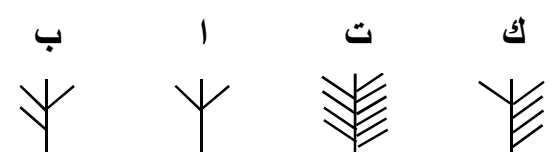

Bu noktada, yukarıda tarif edilen yöntem uyarınca tesis edilen hatt-ı şecerînin bütün karakterlerini gösteren tabloyu sunmakta fayda vardır:

\begin{tabular}{|c|c|c|c|c|c|c|c|c|c|c|c|c|c|}
\hline \multicolumn{4}{|l|}{4} & \multicolumn{3}{|l|}{3} & \multicolumn{3}{|l|}{2} & \multicolumn{4}{|l|}{1} \\
\hline \multicolumn{4}{|l|}{ كلمن } & \multicolumn{3}{|l|}{ حطى } & \multicolumn{3}{|l|}{ هوز } & \multicolumn{4}{|l|}{ ابجد } \\
\hline $\begin{array}{l}\text { ن } \\
50\end{array}$ & $\begin{array}{l}r_{40} \\
40\end{array}$ & $\begin{array}{l}J \\
30\end{array}$ & $\begin{array}{l}5 \\
20\end{array}$ & $\begin{array}{l}\mathrm{v} \\
10\end{array}$ & $\begin{array}{l}b \\
9\end{array}$ & $\begin{array}{l}\tau \\
8\end{array}$ & $\begin{array}{l}j \\
7\end{array}$ & $\begin{array}{l}9 \\
6\end{array}$ & $\begin{array}{l}\circ \\
5\end{array}$ & د & $\begin{array}{l}\text { ج } \\
3\end{array}$ & $\begin{array}{l}\text { ب } \\
2\end{array}$ & $\begin{array}{l}1 \\
1\end{array}$ \\
\hline 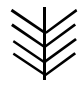 & 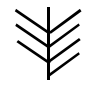 & 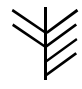 & $\forall$ & $¥$ & $\Psi$ & $Y$ & $\sharp$ & 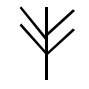 & $\Psi$ & $\mathbb{*}$ & $\forall$ & $\Psi$ & $\psi$ \\
\hline \multicolumn{3}{|l|}{8} & \multicolumn{3}{|l|}{7} & \multicolumn{4}{|l|}{6} & \multicolumn{4}{|l|}{5} \\
\hline \multicolumn{3}{|l|}{ ضظغ } & \multicolumn{3}{|l|}{ ثخذ } & \multicolumn{4}{|l|}{ قرشت } & \multicolumn{4}{|c|}{ سعفص } \\
\hline $\begin{array}{l}\dot{\varepsilon} \\
1000\end{array}$ & $\begin{array}{l}\text { ظ } \\
900\end{array}$ & $\begin{array}{l}\text { ض } \\
800\end{array}$ & $\begin{array}{l}\dot{j} \\
700\end{array}$ & $\begin{array}{l}\dot{\tau} \\
600\end{array}$ & $\begin{array}{l}\stackrel{ث}{5} \\
500\end{array}$ & $\begin{array}{l}ت \\
400\end{array}$ & $\begin{array}{l}\text { ش } \\
300\end{array}$ & $\begin{array}{l}J \\
200\end{array}$ & $\begin{array}{l}\ddot{0} \\
100\end{array}$ & $\begin{array}{l}\text { صo } \\
90\end{array}$ & $\begin{array}{c}\text { ف0 } \\
80\end{array}$ & $\begin{array}{l}\varepsilon \\
70\end{array}$ & س س \\
\hline 信 & 信 & 琂 & 骖 & 骖 & 骖 & 骖 & 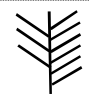 & 骖 & 骖 & $\Downarrow$ & $¥$ & 骖 & $Y$ \\
\hline
\end{tabular}

3 Milli Kütüphanede o6 Hk 3655 arşiv numarasıyla kayıtlı bulunan lugaz mecmuasında, genel hatt-ı şecerî imlasında ortadaki dik çizginin soluna konulan eğik çizgi işareti yerine nokta kullanılmıştır. Bu yazıda sunulan örnekler arasında söz konusu mecmuanın kayıtları da vardır. 
El yazması kayıtlarında görüldüğü kadarıyla hatt-ı şecerî, sayıların şifrelenmesi için de kullanılmıştır. Diğer bir deyişle ebced tertibinden yalnızca harflerin şifrelenmesi için yararlanılmamış, aynı zamanda harflerin rakamsal karşılıklarına istinaden sayılar da şifrelenmiştir. Yukarıdaki tabloda harflerin sayısal karşılıkları bu yüzden tekraren belirtilmiştir. Aşağıdaki el yazması görüntüsünde bu tür kullanımın bir örneği vardır. Metinde 99 sayısı hatt-ı şecerî ile kaydedilmiştir. Böylece büyü veya tılsım benzeri bir uygulamanın tarifini içeren yazıdaki bilgiyi herkesin kullanamaması amaçlanmıştır. Bu durum, bahis konusu şifreli yazının kullanım alanlarından birisinin de okültizm kapsamına dâhil edilebilecek metinler olduğunu göstermektedir. Kayıttaki ilk işaret be (ب), ikincisi fe (ف), üçüncüsü ye (ى), dördüncüsü ise ze (j) harfini karşılayacak şekilde dizilmiştir. Bu harflerin ebced tertibindeki sayısal karşıllıları sırasıyla 2, 80,10 ve 7 olup toplamları 99 sayısını vermektedir.

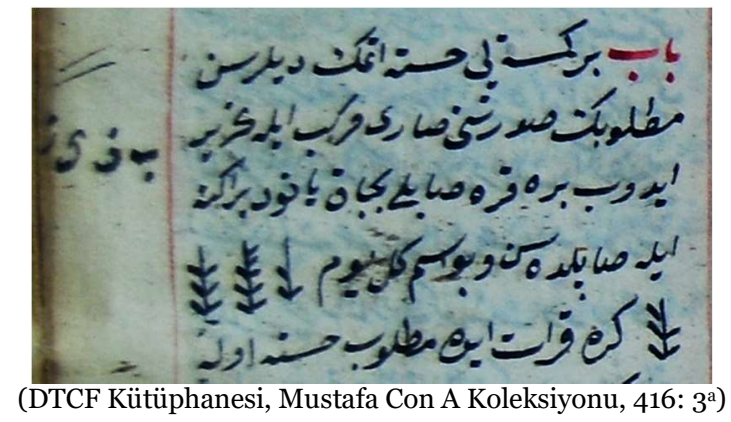

Çelebioğlu'nun da dikkat çektiği üzere (1998: 509), hatt-ı şecerîye, kısaca manzum bilmece olarak tarif edebileceğimiz lugaz türündeki edebî metinleri içeren nüshalarda daha sık tesadüf edilmektedir. $\mathrm{Bu}$ nüshalarda, lugazların cevapları genellikle ilgili şiirin başına hatt-ı şecerî ile kaydedilerek gösterilmiştir. Ancak bu tespitin Türkçe el yazmaları üzerinde yapılan tetkike dayandığını da tekrar hatırlatmak gerekir. Aşağıdaki el yazması kaydında Türkçe bir lugaz ve hatt-ı şecerî ile yazılan cevabı görülmektedir:

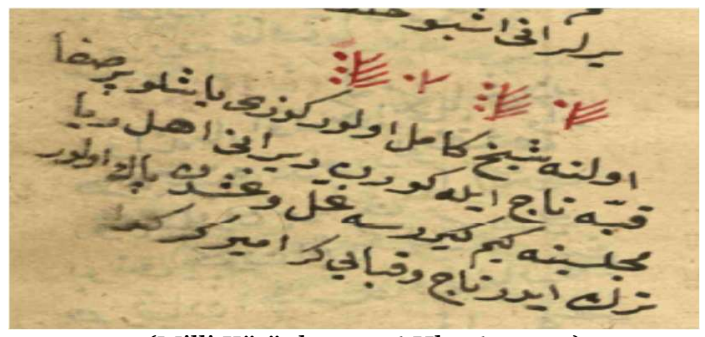

(Milli Kütüphane, o6 Hk 3655: 50ª) (hamâm: حمام)

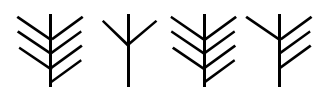

Ol ne şeyh-i kâmil olur gözi yaşlu pür-safâ Kubbe-i tâc ile gören dir anı ehl-i riyâ Meclisine kim girerse gill u gışdan pâk olur Terk ider tâc u kabâyı ger emîr ü ger gedâ

Millet Kütüphanesinde bulunan bir mecmuada, Farsça bir lugazın medlulünün de hatt-ı şecerî ile kaydedildiği görülmektedir. İlgili lugaz, mecmuada muhtelif Farsça şiirlerin arasında kaydedilmiştir. Ancak içindeki Türkçe kayıtlardan anlaşıldığı üzere bu yazma İran'da istinsah edilmemiştir. Ayrıca lugazın cevabının (çekirge) Türkçe olarak gösterilmesi de mecmuanın Türkçe düşünen bir kimse tarafından hazırlandığını teyit etmektedir. Dolayısıyla karşılaşılan bu örnek de Türk geleneğine ait bir mutadın göstergesi olmalıdır. Nitekim kayıtta görülen hatt-ı şecerî modeli de Türkiye'deki yazmalarda karşılaşılan modeli yansıtmaktadır: 


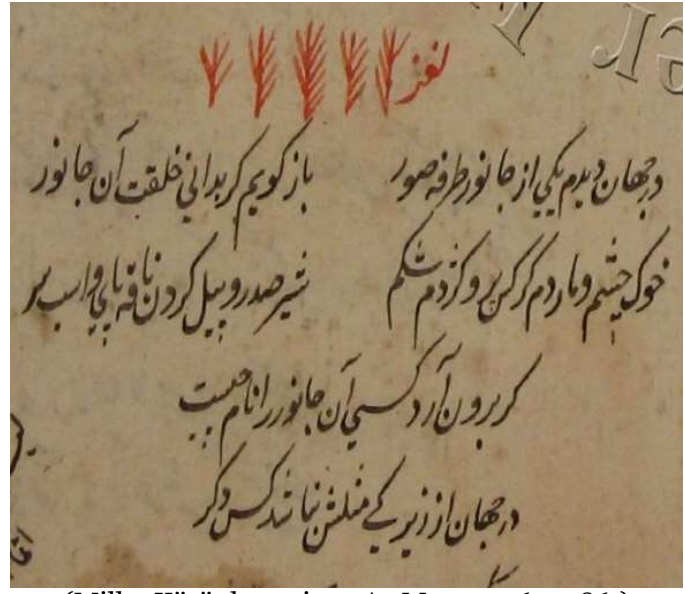

(Millet Kütüphanesi, 34 Ae Manzum 695: 86ª) (çekirge: جִكركه)

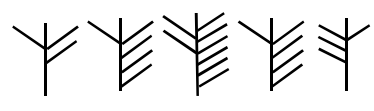

Der-cihân dîdem yekî ez-cânver turfe-suver Bâz gûyem ger be-dânî hilkat-i ân cânver

Hûk-çeşm u mâr-dum kerkes-per u kejdum-şikem Şîr-sadr u pîl-gerden nâke-pây u esb-ser

Ger birûn âred kesî ân cânver-râ nâm çîst Der-cihân ez-zîrekî misleş ne-bâşed kes diger

(Dünyada tuhaf görünüşlü bir yaratı gördüm. Eğer bilirsen sana o yaratı̆̆ anlatayım. Domuz gözlü, yılan kuyruklu, akbaba kanatl, akrep kartnl, arslan göğüslü, deve ayakh ve at başlıdır. Bu yaratı̆̆n isminin ne olduğunu söyleyen kişinin zeka bakımından bir benzeri dünyada yoktur.)

\section{Menşe}

Anlaşıldığı kadarıyla hatt-ı şecerîdeki şifreleme yönteminin mantığı evrensel bir geçerliliğe sahiptir. Bu gizli yazı formunun başka kültürlerde de aynı şekilde kullanıldığına dair herhangi bir belge tespit edilememekle birlikte, hatt-ı şecerînin kurulmasında takip edilen yöntemle örtüşen uygulamaların varlığı bilinmektedir. MÖ 450'de Kleoxeneos ve Demokrotis tarafından geliştirildiği rivayet edilen bir tür harf telgrafı niteliğindeki haberleşme sisteminin yöntemi hatt-ı şecerî ile aynıdır:

"Bu telgraf beş sıra halinde dizilmiş 25 harfin yazılı olduğu bir levhadan oluşuyordu. Sol tarafta önlerine siper konan beş meşale (gündüzleri ise bayrak) iletilmek istenen harfin sırasını gösterirken, aynı anda sağ tarafta, sayısı 1'den 5'e kadar olan meşale ve bayraklarla da sıranın kaçıncı harfinin iletilmek istendiği gösteriliyordu (Faulmann, 2001: 235).”

Bu bilgi, hatt-ı şecerîde uygulanan şifreleme yönteminin geçmişini günümüzden yaklaşı 2500 yıl geriye götürmeyi mümkün kılmaktadır.

İrlanda ve İskoçya'da bulunup I.-VI. yüzyıllara tarihlenen yazıtlardaki Ogham yazısını da bu bağlamda değerlendirebiliriz. Ogham yazısının göstergeleri, temelde her bir ses için muhtelif sayllardaki dik ve eğik çizgilerin teşkilinden oluşmaktadır (Faulmann, 2001: 166). Bu itibarla şekil yönünden hatt-ı şecerî ile kısmen benzer olduğu görülmektedir. Dolayısıyla, hatt-ı şecerî kadar pratik bir yapı arz etmese de, Ogham yazısının da geçmişte yaygın olduğu düşünülebilecek benzer bir yönteme yaslandığı söylenebilir.

El yazmalarında hatt-ı şecerîyi Platon'a nispet eden kayıtlara rastlanması da bu yazının uzak geçmişi ve yaygınlığı hususundaki yorumu destekleyen bir veri olarak değerlendirilebilir. Bu doğrultuda Bursa İnebey Yazma Eser Kütüphanesinde bulunan bir mecmua içinde yer alan Kitâbu'l-Cifr adındaki Arapça kitapta hatt-ı şecerînin Platon’a nispet edildiği görülmektedir: 


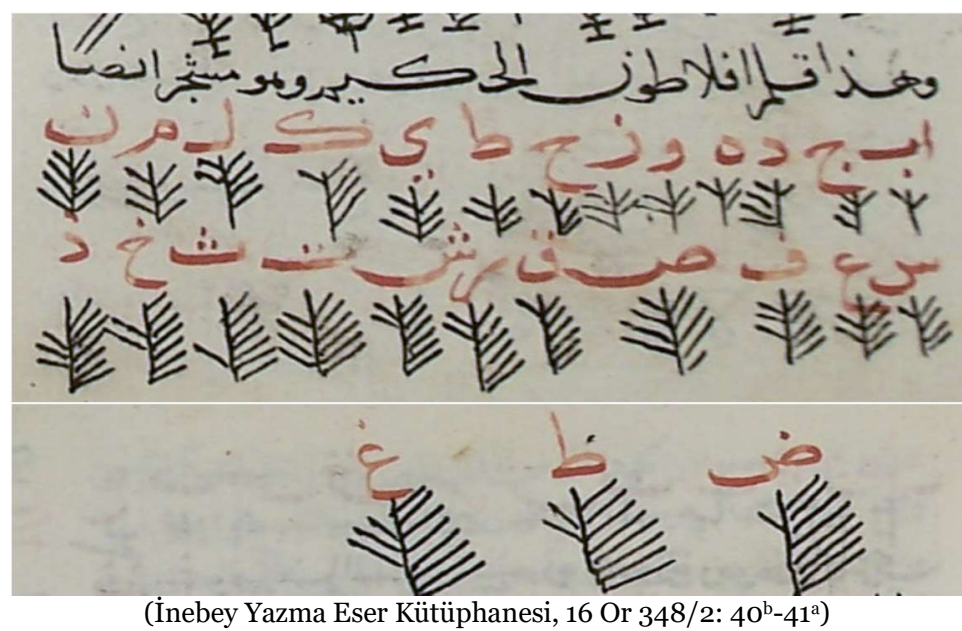

Yine aynı kitapta kalem-i müşeccer adıyla takdim edilen ve miladi 1. asırda Roma ordusunda görev yapmış bir hekim olan (Şen ve Kobaner, 2002) Pedanius Dioskorides'e atfedilen başka bir form daha bulunmaktadır. Şekil bakımından, konumuzu teşkil eden hatt-ı şecerî ile benzeşmekle birlikte daha farklı bir yöntem uygulandığı görülen bu kayıt da ilgili yöntemin geçmişine ve yaygınlığına dair yorum imkânı sağlamaktadır. Âşirefendizâde Mehmed Hafid Efendi de Dioskorides'e atfedilen modele ilişkin bir tablo aktarmıştır (1221: 359-360) Yine Dioskorides'e atfedilen müşeccer formunu içeren başka bir kayıt da Süleymaniye Kütüphanesinde bulunan bir mecmuada tespit edilmiştir (Tökel, 2002). Dioskorides hattının temelde harflerin sayısal karşılıklarını esas alarak tasarlandığı anlaşılmaktadır. Ancak bahsi geçen kayıtlardaki modellerin her birinin farklı olduğunu da belirtmek gerekir:
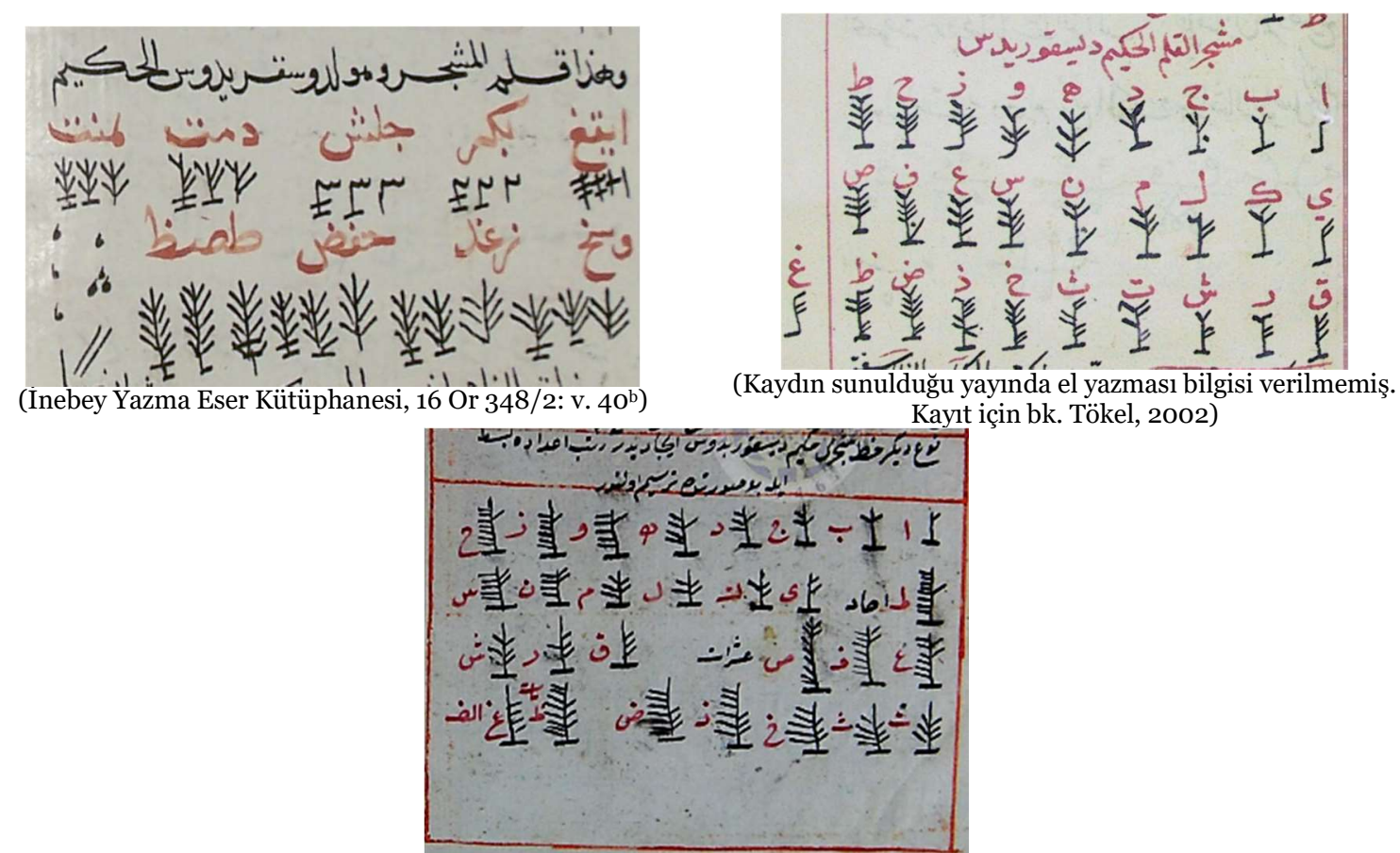

(DTCF Kütüphanesi, Mustafa Con A, 416: 150 ${ }^{\text {b }}$ Bu mecmua kaydl, Hafid Efendi (1221: 359-360)'den aynen iktibastır.)

Arap yazısının kökeni, Nebatî ve Ârâmî silsilesi üzerinden Fenike alfabesine bağlanmaktadır (Çetin, 1991). Bu çerçevede Faulmann da söz konusu alfabeleri Kenan ve Doğu Filistin Yazıları başlı̆̆ı altında tasnif etmiştir (2001: 78-85). İlgili alfabelere bakınca bunların Arap yazısının ilk tasnifi olan ebced 
tertibiyle birebir örtüştüğü görülmektedir. Arap alfabesindeki göstergelerin isimleri de aynı yazı silsilesi içinde yer alan semitik Sâmirîye ve İbrânî göstergelerinin adlandırmalarıyla müşterektir. Tıpkı Arap alfabesinde olduğu gibi bu yazılarda da harflerin sayısal değerleri ve rakamsal fonksiyonu vardır. Söz konusu yazılarda harflere yüklenen sayısal değerler de ebced tertibiyle müşterektir (Faulmann, 2001: 79-80). Farklı olarak Arap alfabesinde fazladan 6 gösterge (ث) ن، خ، ذ، ض، ظ) vardır. Ancak bu göstergeler yazıya eklenirken 22 harfli mezkûr alfabelerin tasnifi bozulmayıp sona eklenmiştir. Nitekim bu harfler ebced tablosunda son iki haneyi teşkil etmektedir. Hatt-ı şecerîyi Antik Çağ filozoflarına nispet eden el yazması kayıtları, Kleoxeneos ve Demokrotis tarafından geliştirilen harf telgrafı sistemi, Dioskorides hattı, Ogham yazısı ve Arap yazısının bahis konusu tarihî kökenleri gibi hususlar birlikte değerlendirilince, hatt-ı şecerîde müşahede edilen şifreleme yönteminin oldukça eski ve evrensel denilebilecek nitelikte yaygın olduğu düşünülebilir.

İlaveten, geçmişte Türkiye ve İran'da halk arasında rastlanan benzer pratikler de ilgili yöntemin yaygınlığı hakkındaki fikri desteklemektedir: Âmil Çelebioğlu, Nahid Aybet'den naklen 1956-1957 tarihlerinde benzer bir formun hallerdeki müstahsil ve kabzımallar arasında özel bir iletişim vasıtası olarak kullanıldığını aktarmıştır (1998: 509). Seyyid Ali Kesâî, Hûş̧eng Câvîd'den naklen hatt-ı şecerînin İranlı kadınlar tarafından kilimlere, döşemelere ve sair el dokumalarına nakşedildiğini aktarmaktadır (1387). Benzer bir şekilde Edward G. Browne da İranlılar Arasında Bir Yıl adlı eserinde hatt-ı şecerîden uyarlanan ve el darbeleriyle harflerin ebced konumunu belirtmeye dayanan bir gizli konuşma yöntemi hakkındaki şahitliğini aktarmıştır (Browne 1387: 408-409'dan aktaran; Kesâî, 1387).

\section{Türler}

Kaynaklardaki bilgilerden hareketle hatt-ı şecerî tasarımlarının temelde üç farklı form arz ettiği söylenebilir. Bunlardan biri Türkiye'de diğeri ise İran'da yaygın olan ve el yazmalarında uygulamalarına tesadüf edilebilen modellere dayanmaktadır. Diğer formsa şimdilik yalnızca kitaplardaki tanımlamalara istinaden bilinip herhangi bir uygulamasına tesadüf edilemeyen Dioskorides hattıdır. Bu itibarla, eski kaynaklardaki tanımlamaları da nazarıdikkate alarak, Türkiye'de yaygın olan hatt-ı şecerî formunu Türk müşecceri, İran'da yaygın olan formu İran müşecceri ve herhangi bir uygulamasına tesadüf edilemeyen üçüncü formu ise Dioskorides müşecceri başlığı altında tasnif edebiliriz. Bu formların her biri aşağıda müstakil başlıklar altında tanıltılmıştır.

\section{a. Türk müșecceri}

Yazının başından itibaren tanımını yapıp örneklerini aktardığımız form, Türkiye'deki hatt-ı şecerî pratiğini yansıtmaktadır. Yine bu yazının $E k$ kısmında sunulan el yazması kayıtları da Türk kaynaklarından alınmıştır ve aynı modeli örneklemektedir. Dolayısıyla bu başlık altında aynı bilgileri tekrar etmeye gerek görülmemiştir. Bu itibarla kısaca, makalenin girişinden itibaren tanıtımı yapılıp örnekleri sunulan ve $E k$ başlığında başka numunelerine de yer verilen hatt-ı şecerî modeli Türk müşecceri olarak tanımlanabilir. Yine aşağıdaki el yazması örneği de bu modeli gösterir bir kayıttır: 


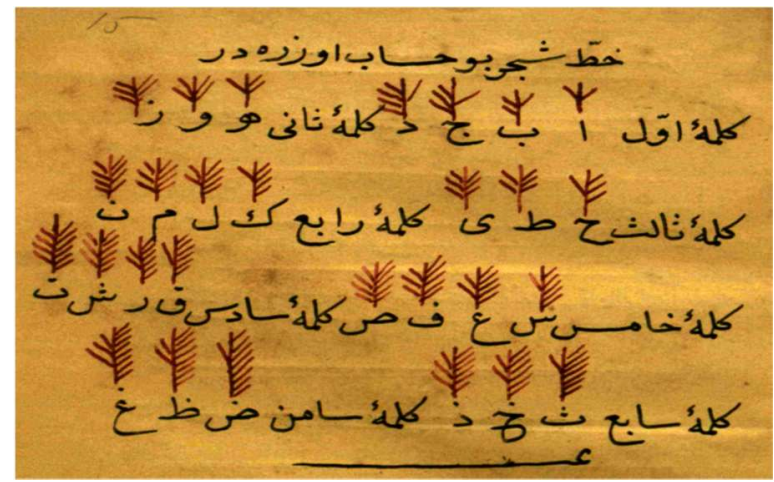

(Milli Kütüphane, o6 Mil yz A 2714: 15a)

Türkçe el yazmalarındaki uygulamalarından hareketle Türk müşeccerinin temelde üç kullanım alanından söz edilebilir. Bunlardan ilki ve aynı zamanda en sı rastlanılanı, lugaz türündeki metinleri içeren el yazmalarıdır. İlgili kayıtlardan iki örnek yukarıda, iki örnek de $E k^{\prime}$ te takdim edilmiştir. İkinci kullanım alanı; herkesin elde etmesi istenilmeyen bazı bilgileri şifrelemek amacıyla fal, büyü, tılsım, cifr ve vefk gibi gizli uğraşlarla ilgili metinlerdir. Yukarıda takdim edilen ilk örnek, bu türden bir metinden alınmıştır. Türk müşeccerinin üçüncü kullanım alanını ise kitabetle ilgili muhtelif kayıtlar olarak gösterebiliriz. ${ }^{4}$

\section{b. İran müsşecceri}

En eskisinden en yenisine kadar İran'daki bütün kaynakların (Nerâkî, 1380; Kesâ̂̂, 1387; Zâkirî, 1388; Muhammedî-Feşârekî ve Şîrânî, 1390) ittifak ettiği hatt-ı şecerî formu, Türk modelinden farklı bir yapı arz etmektedir. Dolayısıyla İran'a mahsus bir geleneği yansıttığı anlaşllan bu modeli İran müşecceri olarak tasnif etmek mümkündür. İran müşeccerinin Türk formundan temel farkı ebced hanelerinin gösterilme usulünden kaynaklanmaktadır. Türk müşeccerinde ebced kelimeleri ilk haneden itibaren yazının sağına konulan eğik çizgilerle belirlenmiştir. İran müşeccerinde ise ilk hane için herhangi bir çizgi konulmayıp çizgiler ikinci haneden itibaren başlamaktadır. Dolayısıyla Türk müşeccerinde elif (') harfine karşıllk gelen gösterge, İran müşeccerinde he (॰) harfini karşlamaktadır. Bu itibarla söz konusu iki üsulden birine aşina olup diğeri hakkında bilgisi olmayanların hataya düşmeleri muhtemeldir. İran müşeccerinin bütün karakterlerini aşağıdaki gibi gösterebiliriz:

\begin{tabular}{|c|c|c|c|c|c|c|c|c|c|c|c|c|c|}
\hline $\begin{array}{l}\dot{ن} \\
50\end{array}$ & $\begin{array}{l}\text { r } \\
40\end{array}$ & $\begin{array}{l}J \\
30\end{array}$ & $\begin{array}{l}5 \\
20\end{array}$ & $\begin{array}{l}\checkmark \\
10\end{array}$ & $\begin{array}{l}b \\
9\end{array}$ & $\begin{array}{l}\tau \\
8\end{array}$ & $\begin{array}{l}j \\
7\end{array}$ & $\begin{array}{l}9 \\
6\end{array}$ & $\begin{array}{l}\circ \\
5\end{array}$ & $\begin{array}{l}2 \\
4\end{array}$ & $\begin{array}{l}\text { ج } \\
3\end{array}$ & $\begin{array}{l}\dot{y} \\
2\end{array}$ & $\begin{array}{l}1 \\
1\end{array}$ \\
\hline$\sharp$ & $¥$ & $\Psi$ & $Y$ & $\Downarrow$ & $¥$ & $Y$ & $\sharp$ & $\Downarrow$ & $Y$ & $\forall$ & $\mathbb{F}$ & $\bigvee$ & $Y$ \\
\hline $\begin{array}{l}\dot{\varepsilon} \\
1000\end{array}$ & $\begin{array}{l}\text { ظ } \\
900\end{array}$ & $\begin{array}{l}\text { ض } \\
800\end{array}$ & $\begin{array}{l}\dot{j} \\
700\end{array}$ & $\begin{array}{l}\dot{\tau} \\
600\end{array}$ & $\begin{array}{l}\dot{ث} \\
500\end{array}$ & $\begin{array}{l}ت \\
400\end{array}$ & $\begin{array}{l}\text { ش } \\
300\end{array}$ & $\begin{array}{l}J_{200} \\
200\end{array}$ & $\begin{array}{l}\text { ق } \\
100\end{array}$ & $\begin{array}{l}\text { صo } \\
90\end{array}$ & $\begin{array}{l}\text { ف0 } \\
80\end{array}$ & $\begin{array}{l}\varepsilon \\
70\end{array}$ & $\begin{array}{l}\text { س } \\
60\end{array}$ \\
\hline 非 & 非 & 非 & 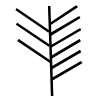 & 骖 & 骖 & 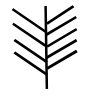 & 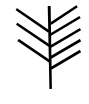 & Y & $Y=$ & $\forall$ & 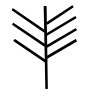 & 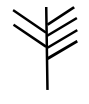 & $Y=$ \\
\hline
\end{tabular}

Konu hakkında yapılan yayınlarda bu yazının, İran'daki el yazmalarında hangi türdeki metinlerde veya ne amaçla kullanıldığına dair tespitlere yer verilmemiştir. İlgili yayınlarda sunulan sınırlı sayıdaki

4 Müstensih künyesinin hatt-ı şecerî ile kaydedildiği bir önek için bk. Egüz, 2010. 
örnekten (Kesâî, 1387) anlaşıldığı kadarıyla hatt-ı şecerînin İran el yazmalarındaki kullanım alanlarından biri -Türkçe el yazmalarında da görüldüğü üzere- kitabet kayıtlarıdır.

\section{c. Dioskorides müşecceri}

Yukarıda da değinildiği üzere Dioskorides müşecceri harflerin sayısal karşılıklarını esas alan ve onlu sayı sistemine göre tertip edilen bir modeldir. Buna göre alfabedeki 1-9 arasında sayısal değere sahip olan göstergeler dik çizginin sağına bir çizgi, 10-90 arasında değere sahip olanlar iki çizgi, 100-900 arasında değere sahip olanlar üç çizgi ve son olarak 1000 göstergesi (غ) de dört çizgi çekilmek suretiyle belirtilmiştir. Aralardaki göstergelerse sola çekilen çizgilerle belirtilmiştir. İran müşeccerine benzer bir şekilde sola çekilen çizgilerle belirtilen ara göstergelerin ilki için hiç çizgi konulmayıp ikinci göstergeden itibaren çizgi çekilmeye başlanmıştır. Örneğin 1 sayısı için dik çizginin sağına tek çizgi çekilip solu boş bırakılmış, 2 sayısı içinse sol tarafa bir çizgi çekilmiştir. Kayıtlarda görülen bütün modellerde dik çizginin altında kaide niteliğinde bir düz çizginin de var olduğu görülmektedir. Bu sebeple aşağıdaki tabloda da bu özelliğin yansıtılmasına dikkat edilmiştir. Hafid Efendi'nin nakline göre Dioskorides müşecceri aşağıdaki gibidir (1221: 359-360):

\begin{tabular}{|c|c|c|c|c|c|c|c|c|c|c|c|c|c|}
\hline $\begin{array}{l}50 \\
ن\end{array}$ & $\begin{array}{l}40 \\
?\end{array}$ & 30 & $\begin{array}{l}20 \\
5\end{array}$ & $\begin{array}{l}10 \\
ى\end{array}$ & $\begin{array}{l}9 \\
b\end{array}$ & $\begin{array}{l}8 \\
\tau\end{array}$ & $\begin{array}{l}7 \\
j\end{array}$ & $\begin{array}{l}6 \\
9\end{array}$ & $\begin{array}{l}5 \\
0\end{array}$ & $\begin{array}{l}4 \\
2\end{array}$ & $\begin{array}{l}3 \\
\text { ج }\end{array}$ & ب 2 & $\begin{array}{l}1 \\
1\end{array}$ \\
\hline$\sharp$ & $¥$ & $\forall$ & $Y$ & & & $\mathbb{8}$ & & & & & & & \\
\hline $\begin{array}{l}1000 \\
\dot{\varepsilon}\end{array}$ & $\begin{array}{l}900 \\
\text { ظ }\end{array}$ & $\begin{array}{l}800 \\
\text { ض }\end{array}$ & $\begin{array}{l}700 \\
\text { ذ }\end{array}$ & $\begin{array}{l}600 \\
\dot{\tau}\end{array}$ & $\begin{array}{l}500 \\
\vdots\end{array}$ & $\begin{array}{l}400 \\
ت\end{array}$ & ش ش 300 & $\begin{array}{l}200 \\
ر\end{array}$ & $\begin{array}{l}100 \\
\text { ق }\end{array}$ & ص 90 & $\begin{array}{l}80 \\
\text { ف }\end{array}$ & & $\begin{array}{l}60 \\
60\end{array}$ \\
\hline$\underline{E}$ & $\mathbb{S}$ & 证 & 徏 & 丑 & 非 & $\Psi$ & $\Psi$ & $\underline{E}$ & $\underline{E}$ & 新 & $\mathbb{8}$ & 売 & 政 \\
\hline
\end{tabular}

Tabloda vurgulandığı üzere Dioskorides müşeccerinin harflerden ziyade sayıları göstermek için tasarlandığını ve muhtemel kullanım alanının da sayısal metinler olduğunu söyleyebiliriz. Dahası, bu model gerçekten de kaynaklarda ifade edildiği gibi I. asırda yaşamış Dioskorides tarafından ihdas edilmişse, Roma rakamlarından kaynaklanan müşkülleri aşmak gibi bir amaca matufen, hatt-ı şecerîde de akis bulan söz konusu yaygın yöntemden istifade ile tasarlandığı düşünülebilir.

Hatt-ı şecerînin türleri konusunda değinilmesi gereken bir diğer husus ise bu mefhumun başka alanların kavramlarıyla müşterekliği meselesidir. Hat sanatında ağaç dalını andıracak şekilde düzenlenen ve sanat değeri açısından kayda değer görülmeyen (Derman, 1997) yazılar da hatt-ı şecerî ve kalem-i müşeccer tabirleriyle anılmıştır (bk. Ek 5). Bunun dışında tecvit literatüründeki hurûf-ı şecerî kavramı da hatt-ı şecerîyi çağrıştırmaktadır. Tecvitteki hurûf-ı şecerî kavramı, dilin ortasının üst damak ortasına temasıyla çıkarılan sesleri karşılayan şın (ش), cim (ج) ve ye (ى) harflerini kasten kullanılmıştır (Kesâî, 1387). Her iki örneğin de esas mevzumuzu teşkil eden hatt-ı şecerî ile hiçbir alakası yoktur.

\section{Sonuç}

Bir şifreli yazı dizgesi olan hatt-ı şecerî, standart Arap alfabesinin ebced tertibinden faydalanılarak tasarlanmıştır. Şekil bakımından basit bir ağaç çizimini andırdığı için mezkûr adla anıldığı anlaşılan yazı, kaynaklarda hatt-ı nahlî, hatt-ı servî, hatt-ı şecer, kalem-i miscer, kalem-i müşeccer, kalem-i serv ve kalem-i şecerî tabirleriyle de ifade edilmiştir. 
Bazı kaynaklarda Platon'a nispet edilen hatt-ı şecerî yazısının tesis edilmesinde kullanılan yöntem, farklı amaç ve araçlarla tarihte başka kültürlerce de kullanılmıştır. Dolayısıyla söz konusu şifreleme yönteminin köklü bir geçmişe sahip evrensel bir uygulama olduğu ve hatt-ı şecerînin de söz konusu yöntemin bizim kültürümüzdeki yansıması olduğu anlaşılmaktadır.

El yazmalarında tespit edilen örneklerinden hareketle hatt-ı şecerînin temelde üç farklı tasarıma sahip olduğu görülmüsştür. Bu yazıda, söz konusu tasarımlardan ikisi revaç buldukları kültüre nispetle, diğeri de kaynaklarda ilgili modelin sahibi olarak anılan şahsın adıyla kavramsallaştırılmıştır. Böylece bahse konu şifreli yazı Türk müşecceri, İran müşecceri ve Dioskorides müşecceri olmak üzere üç başlık altında tasnif edilmiştir.

Tespit edilen örneklere göre hatt-ı şecerî genel olarak şu üç amaçla kullanılmıştır: a) Lugaz türündeki metinleri içeren el yazmalarında ilgili şiirin cevabına medlulen. b) Metinlerde herkesin anlaması istenilmeyen bazı bilgileri şifrelemek. c) Kitabetle ilgili muhtelif bilgileri kaydetmek.

\section{Kaynakça}

Âşirefendizâde Mehmed Hafid Efendi. (1221 (1806)). Ed-Dürerü'l-Müntehabâti'l-Mensûre fí-Islâhi'lGalatâti'l-Meşhûre. İstanbul: Dâru't-Tıbâ'a.

Browne, E. G. (1387). Yek Sâl Der-Miyân-i Îrâniyân. (M. Sâlihî-Allâme, Çev.) Tahran: Neşr-i Ahterân.

Cönk. Atatürk Kitaplığı Koleksiyonu, Arşiv No: MC_Yz_K_0554_01.

Çelebioğlu, Â. (1998). Kültür ve Edebiyatımızda Şifre Alfabeleri. Eski Türk Edebiyatı Araştırmaları (s. 505-518). içinde İstanbul: Milli Eğitim Bakanlığı.

Çetin, N. M. (1991). Arap (II. Yazı). Diyanet İslâm Ansiklopedisi (Cilt 3, s. 276-309). içinde İstanbul: İSAM.

Decourdemanche, M. J. A. (1899). Note Sur Quatre Systèmes Turcs de Notation Numérique Secrète. Journal Asiatique(14), 258-271.

Derman, M. U. (1997). Hat. Diyanet İslâm Ansiklopedisi (Cilt 16, s. 427-437). içinde İstanbul: İSAM.

Egüz, E. (2010). Priştineli Begzâde Nûrî Divanı ve Divan'daki Şifreli Yazılar. Selçuk Üniversitesi Türkiyat Araştırmaları Dergisi(27), 297-311.

Faulmann, C. (2001). Yazı Kitabı (Tüm Yerkürenin, Tüm Zamanların Yazı Göstergeleri ve Alfabeleri). (I. Arda, Çev.) İstanbul: Türkiye İş Bankası Kültür Yayınları.

Harekât, İ. (1992). Berîd. Diyanet İslâm Ansiklopedisi (Cilt 5, s. 498-501). içinde İstanbul: İSAM.

Havâs ve Fâl Mecmû́ası. Ankara Üniversitesi DTCF Kütüphanesi. Mustafa Con A Koleksiyonu, Demirbaş: 416.

Karabey, T. (2015). Türk Edebiyatında Tarih Düşürme. Ankara: Atatürk Kültür Merkezi.

Kesâî, S. (1387). Hatt-i Şecerî. Âyine-i Mîrâs, 6(3), 186-199.

Kitâbu’l-Cifr. Bursa İnebey Yazma Eser Kütüphanesi, Arşiv No: 16 Or 348/2.

Lugazât. Milli Kütüphane, Arşiv No: 06 Hk 3655.

Mânî, türkü ve şarkılar mecmu'ası. Millet Kütüphanesi. Ali Emiri Koleksiyonu, Arşiv No:34 Ae Manzum 752 , v. $2^{\mathrm{a}}$.

Mecmu'a. Milli Kütüphane, Arşiv No: 06 Mil yz A 2714.

Mecmu'a-i Eş 'âr. Millet Kütüphanesi, Arşiv No: 34 Ae Manzum 695.

Muhammedî Feşârekî, M., \& Şîrânî, M. (1390). Hatt-i Mu'ammâ (Pijûhiş Der-Envâ' ve Şîvehâ-yi Remznigârî-i Munşa'ât). Pijûhişhâ-yi Zebân ve Edebiyyât-i Fârisî ('İlmî-Pijûhişî), 3(3), 109-134. 
Nerâkî, A. (1380). Hazâ'in. (H. Hasanzâde-Amelî, \& A. Gaffârî, Dü) Tahran: Kitâbfurûşî̀i İlmiyye-i İslâmiyye.

Osmanh \& Karma Sanat Eserleri Müzayedesi (26.05.2018) Kataloğu. alifart.com (Erişim Tarihi: 10.07.2019): https://www.alifart.com/dort-adet-hat-levhasi_271105/

Şen, H., \& Kobaner, M. (2002). Anavarzalı Dioskorides. Sürekli Tip Eğitimi Dergisi (STED), 11(10), 392394.

Şenödeyici, Ö. (2008). Osmanlı'nın Görsel Şiirleri II -Şiir Çizmek Sanatı ve Geometrik Şekillerde Denge. Uluslararası Sosyal Araştırmalar Dergisi, 1(4), 543-565.

Şenödeyici, Ö. (2009). Osmanlı'nın Görsel Şiirleri I: Resim Yazmak Sanatı ve Sâdıkî'ye Ait Bir Müşeccerin Tetkiki. Türklük Bilimi Araştırmaları (TÜBAR)(26), 217-227.

Şenödeyici, Ö. (2012). Osmanlının Görsel Şiirleri. İstanbul: Kesit.

Tökel, D. A. (2002). Alfabeden Simgeye, Simgeden Şifreye: Kadîm Milletlerin Alfabelerine Dair Arapça Bir Risale. Nüsha, 2(6), 169-181.

Uzun, M. (1994). Ebced. Diyanet İslâm Ansiklopedisi (Cilt 10, s. 68-70). içinde İstanbul: İSAM.

Zâkirî, M. (1388). İbdâ'-i Hutût-i Remzî Der-Ferheng-i İslâmî ve Îrânî. Âyine-i Mîrâs(45), 121-142. 
340 / RumeliDE Journal of Language and Literature Studies 2019.16 (September)

The reflection of an ancient encryption method in Islamic culture: Ḥațti shajarī / B. Taş (p. 328-339)

\section{$\mathbf{E k}$}

1.

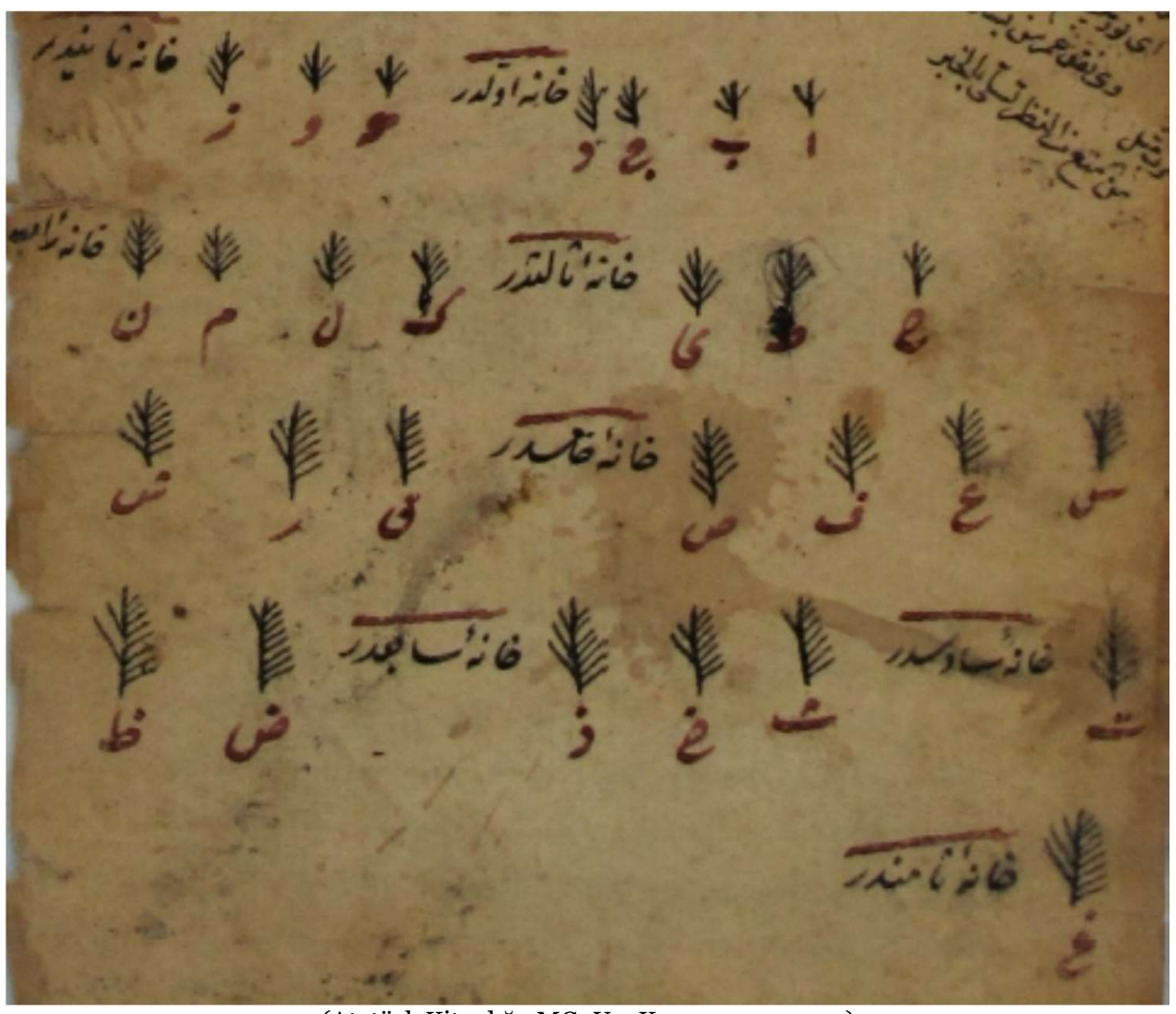

(Atatürk Kitaplığı, MC_Yz_K_0554_01: 102ª.)

2.

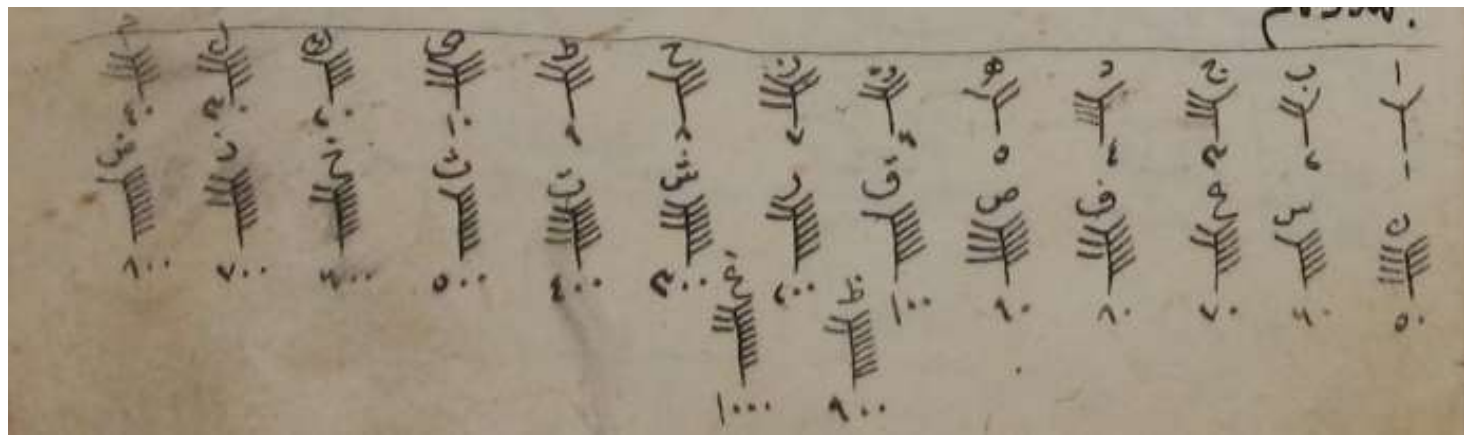

(Millet Kütüphanesi, 34 Ae Manzum 752: $2^{\mathrm{a}}$.)

Adres
Adress

Kirklareli University, Faculty of Arts and Sciences, Department of Turkish Language and Literature, Kayalı Campus-Kırklareli/TURKEY e-mail: editor@rumelide.com 
3 .

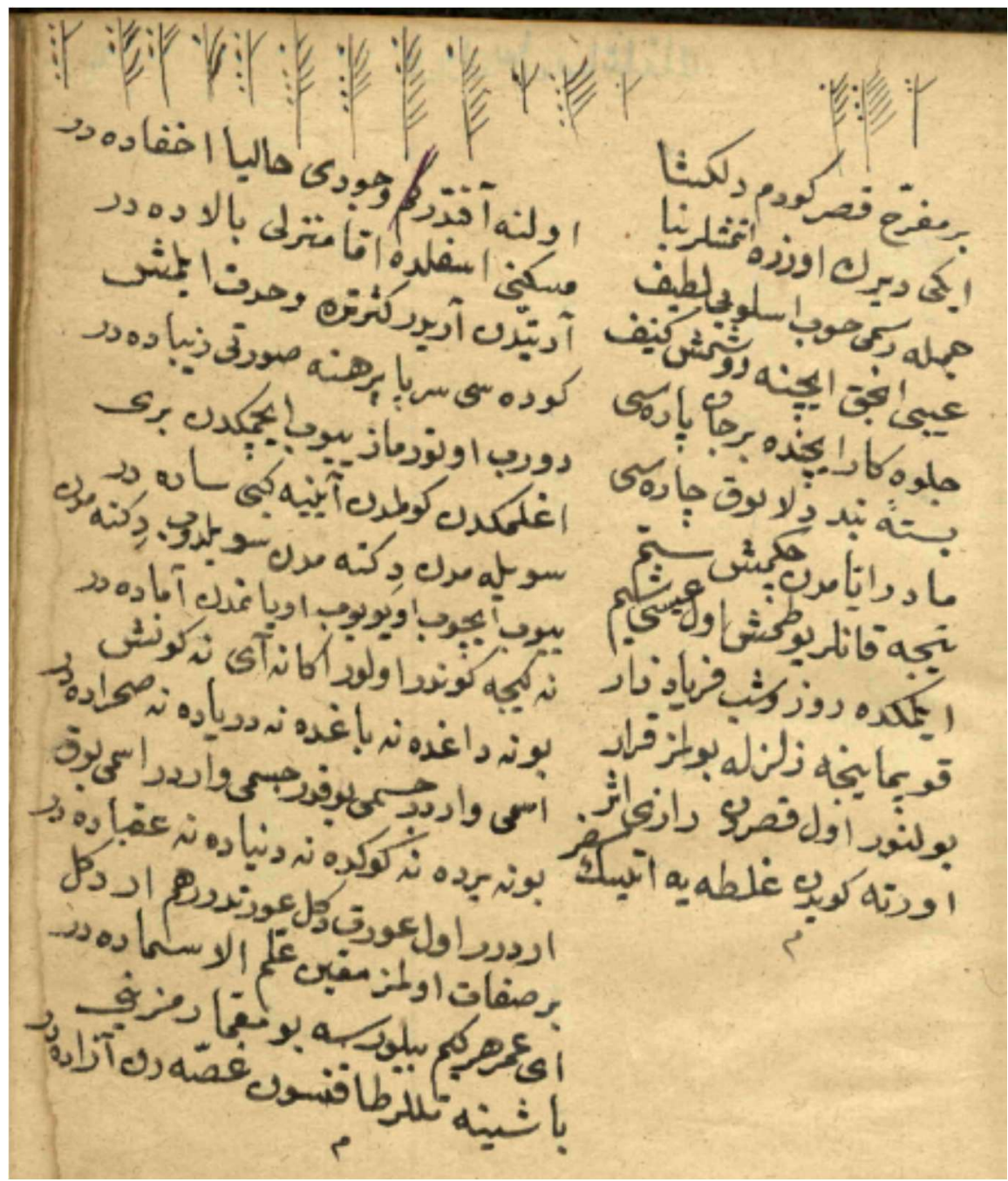

(Milli Kütüphane, o6 Hk 3655: 9a)

4 .

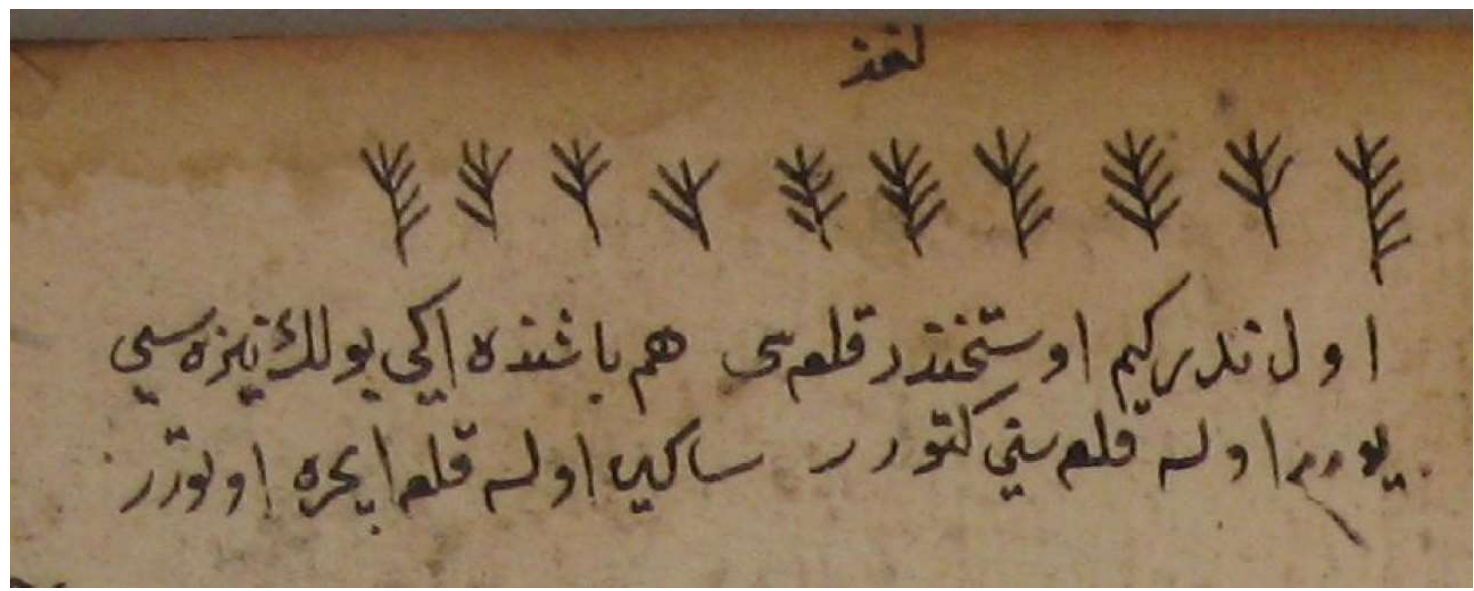


342 / RumeliDE Journal of Language and Literature Studies 2019.16 (September)

The reflection of an ancient encryption method in Islamic culture: Ḥațti shajarī / B. Taş (p. 328-339)

(Millet Kütüphanesi, 34 Ae Manzum 695: 86a)

$5 \cdot$

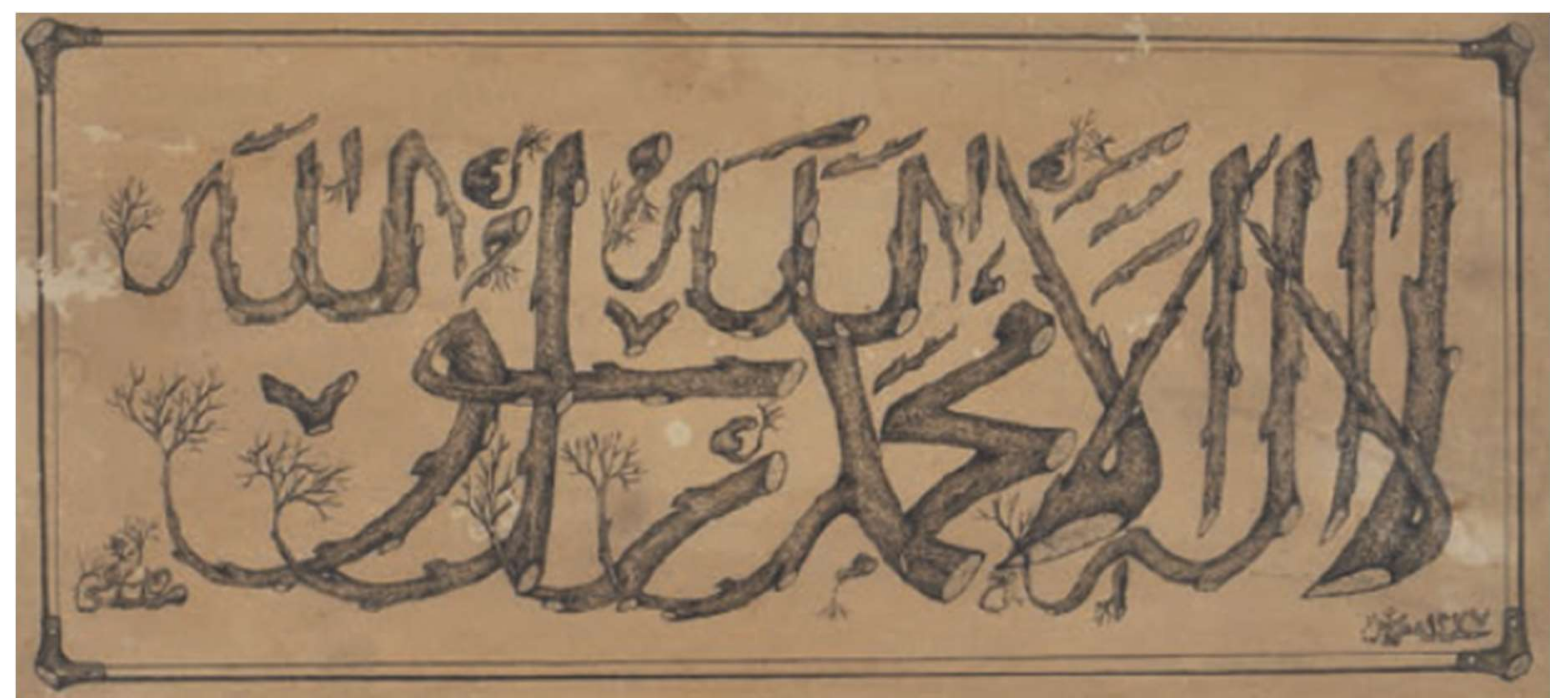

(Hat sanatına ait bir şecerî/müşeccer yazı örneği: alifart.com) 